Ružica Cacanoska, Skoplje

Dragan Todorović, Niš

\title{
IVAN CVITKOVIĆ KAO SOCIOLOG RELIGIJE: ŠEST NEZAOBILAZNIH KNJIGA
}

\section{Sociologija obreda}

U sociologiji religije klasična religioznost određuje se kao jedinstvo religiozne svesti i religioznog ponašanja i udruživanja. Uz deklarisanje u religijskim terminima, neophodno je i na propisan način obavljati obrede i redovno prelaziti prag hrama (Blagojević 2005: 63). Odbacuje se subjektivna religioznost bez crkvenosti, budući da većina verskih struktura zahteva pravovernost iskazanu i kroz svakodnevno praktično potvrđivanje verničkog statusa (Đorđević - Todorović 2001: 157).

U društvenim naukama najčešće se sinonimno označavaju termini ritual, obred, ceremonija, svetkovina i sl. (Povrzanović 1987). U zavisnosti od predmeta proučavanja, i od teorijskoga polazišta autora, mogu da se naprave izvesne značenjske razlike: "Termin obred uglavnom se dovodi u vezu s religijskom sferom, dok ritual ima širi značenjski sadržaj, pa shodno tome i primjenjivost. On može imati, u većoj ili manjoj mjeri, izražen religijski karakter, ali može biti i sekularne prirode” (Đurić Đorđević 2010: 167). Ili: “Obred (rite) je element svakog rituala, odnosno to je konkretna aktivnost ili praksa u ritualu. Svaki ritual je izgrađen od jednog ili više obreda. Kao praktična strana rituala, obred je njegov esencijalni deo... Ritualizovanjem određene aktivnosti stvara se veza između svetog i profanog sveta, jer su obredi posvetovljene aktivnosti svakodnevnog života čijim izvođenjem na specijalno odabranom mestu i vremenu, strogim poštovanjem pravila, nastaje ritual" (Pejić 2017: 16-17). U Rječniku sociologije i socijalne psihologije Oleg Mandić obred određuje kao "formalni religijski čin koji se vrši po pravilima što ih određuje rukovodstvo institucionalizirane religije da bi se javno ispoljilo štovanje božanstava, svetaca ili drugih nadnaravnih snaga koje obožavaju njezini vjernici, i da bi se točnim izvršavanjem svih njegovih komponenata ispunili uvjeti za stjecanje božje milosti” (Bosanac - Mandić - Petković 1977). 
U različitim teorijskim diskusijama ritual se najpre shvata kao delovanje, čime se odvaja od konceptualnih, odnosno misaonih aspekata religije poput verovanja, simbola i mitova (Bell 2009). "Edvard Šils, recimo, smatra da su ritual i verovanje istovremeno i povezani i odvojeni, budući da je moguće da neko prihvata samo verovanja, ali ne i s njima povezane ritualne aktivnosti. Verovanje, zaključuje Šils, 'može egzistirati nezavisno od rituala. Nasuprot tome, bez verovanja nema rituala"' (Shills 1968; citirano prema: Bell 2009: 19). Za Meredit Makgvajer (Meredith McGuire) putem obrednih aktivnosti grupa pamti sopstvena zajednička značenja: "To ima značajne posljedice i za grupu i za sve pojedinačne članove. Grupa obnavlja svoj zanos i smisao ujedinjenosti, a pojedinci se identificiraju sa grupom i njenim ciljevima" (McGuire 1992: 17).

O društvenim funkcijama religijskih obreda dosta se raspravljalo u antropologiji i sociologiji (Malinovski 1972; Dirkem 1982; Radcliff-Brown 1952; Turner 1977; Gerc 1998; Van Genep 2005). U okviru funkcionalističkog pristupa, Emil Dirkem (Durkheim) pod pojam ritual svodi obrede, ceremonije i sve druge radnje koje za cilj imaju jačanje kolektivne svesti ili moralnih ideala društva skrivenih pod maskom religije (Dirkem 1982). Bronislav Malinovski (Malinowski) iz perspektive individualnih psiholoških stanja ritual posmatra kao aktivnost koja ima funkciju izražavanja emocija i smanjivanja anksioznosti, straha, patnje, nesigurnosti (Malinovski 1979). Ritual je za Alfreda Radklif-Brauna (Radcliff-Brown) oblik kolektivne akcije članova društva koja je propisana običajima, izvodi se u situacijama promena u društvenom životu i omogućava opstanak društvenih veza i odnosa među članovima društva. Arnold van Genep (van Gennep) piše o tzv. obredima prelaza, naglašavajući tri faze kroz koje rituali prolaze: odvajanje, tranzicija i reintegracija, čime se omogućava opstanak i integracija društva, ali i unose promene. Viktor Tarner (Turner) dodatno razlikuje dve vrste rituala: rituali životnih kriza i rituali pročišćenja usled posednutosti (Turner 1969/1977). Za Edmunda Liča (Leach) takođe "velika većina ceremonijalnih prigoda u svim ljudskim društvima, predstavlja 'obrede prelaza' koji označavaju granice između jedne i druge društvene kategorije” (Lič 1983: 56). Kliford Gerc (Geertz) ritual posmatra kao model komunikativnog ponašanja koji funkcioniše da bi obezbedio religijska raspoloženja i motivacije, ali ne i da transformiše društvene odnose (Gerc 1998).

U Elementarnim oblicima religijskog života Dirkem piše da obredi prate verovanja i čine vezu između pojedinca, grupe i društva, koja se u obredu rađa i periodično obnavlja: "U osnovi svih sistema verovanja i svih kultova nužno mora počivati izvestan broj osnovnih predstava i obrednih ponašanja koja, uprkos raznovrsnosti oblika što su ih mogla zaodenuti, svuda imaju isto 
objektivno značenje i svuda ispunjavaju iste funkcije" (Dirkem 1982: 7). Definiše ih kao "pravila ponašanja koja propisuju kako čovek mora da se vlada sa svetim stvarima" (Dirkem 1982: 35) ili još preciznije, kao "mit pretočen u delo" (Dirkem 1982: 75) i deli na negativne i pozitivne. Skup obrednih radnji čiji je cilj uređivanje i organizovanje pozitivnog odnosa čoveka sa religijskim silama naziva se pozitivni kult (Dirkem 1982: 275-298). Skup obrednih radnji čiji je cilj sprečavanje mešanja ili zbližavanja svetih i profanih bića putem niza uzdržavanja i zabrana naziva se negativni kult (zabrane dodira, zabrane opštenja, obredi u kojima se nanosi bol i sl.). Ali, negativni kult uči članove jednog društva o važnosti i značenju odricanja (Dirkem 1982: 299-376). Religijski život odvija se isključivo na svetim mestima, tamo gde je sveto prostorno odvojeno od profanog (hramovi i svetilišta) i u svetom vremenu (religijski praznici). Zajedničko obeležje obreda je da se periodično obnavljaju, čime se obnavljaju i kolektivne predstave jednog društva. Ovakav Dirkemov pristup pogodovao je sociološkom proučavanju religije kao sistema društvenih odnosa, odnosno kao univerzalne dimenzije društvenog života (detaljnije u: Pejić 2017: 174-181).

Upravo na ovom tragu, prepoznajući da su "onaj vanjski, vidljivi, 'opipljivi' oblik religioznosti” (Cvitković 2014: 20) i "zato jer obredi izražavaju, održavaju i obnavljaju jedinstvo i identitet grupe" (Cvitković 2014: 24), Ivan Cvitković piše svoju Sociologiju obreda (2014).

Pored uvoda, spiska korišćene literature, imenskog i pojmovnog registra, knjigu čine 12 poglavlja sa potpoglavljima: 1. Pojam obreda (Razlika između običaja i obreda; Funkcija obreda; Obredna sredstva; Zabrana sudjelovanja u obredima), 2. Dobni obredi (Obredi rođenja; Obredi imenovanja (imendanski obredi); Inicijacijski obredi; Obrezanje; Obredi pri sklapanju braka; Pogrebni obredi; Komemorativni obredi), 3. Obredi očišćenja (Abdest; Obred pričesti; Obredno kupanje; Ostali obredi očišćenja), 4. Blagdanski obredi, 5. Obredi hodočašća, 6. Obredi zahvalnosti, 7. Gozbeni obredi, 8. Kalendarski obredi, 9. Obredi žrtvovanja, 10. Ratni obredi, 11. Ostali obredi (Tabui; Obredni ples; Obredna glazba; Obredi proricanja; Magijski obredi; Karnevalski obredi; Seksualni obredi; Obredi iscjeljenja) i 12. Ekskurs o obredima u "svjetovnoj religiji”. Na blizu 400 stranica sistematično se predstavljaju religijski obredi iz religijskih tradicija Afrike, Polinezije, Indije i Dalekog istoka, ali i religijska praksa savremenih monoteističkih religija i novih religijskih pokreta.

Teško je zamisliva religija bez obreda, jer baš zahvaljujući njima "postaje dostupna vernicima" (Cvitković 2014: 12), kao što se i same religije međusobno razlikuju prema specifičnim obredima koje praktikuju. Obredi se odvijaju prema strogo propisanim pravilima, a odobravaju ih pisani religijski 
autoriteti (po čemu se razlikuju od običaja) ili su "dugotrajno nastajali kao dio religijske kulture i tradicije neke društvene zajednice" (Cvitković 2014: 14). Nekolike su im funkcije: integrativna, emocionalna, komunikacijska, funkcija regulisanja frustracija i emocija u kriznim životnim periodima, etička, te funkcija identitetskog znaka. Uz mnoštvo ilustracija, Cvitković navodi koji se sve elementi mogu naći u poziciji obrednih elemenata (tamjan, zvono, krst, vino, hleb, reč, sveta voda, sveto posuđe, relikvije, cveće, brojanice, odeća, čak i droga).

Posebno mesto posvećeno je tzv. porodičnim ili obredima prelaza (obredi rođenja, imendanski obredi, inicijacijski obredi, obredi obrezanja, obredi pri sklapanju braka, pogrebni i komemorativni obredi), jer "znače verifikaciju prijelaza iz jednog društvenog statusa u drugi” (Cvitković 2014: 58), kao i obredima očišćenja, jer u maltene svim religijama pristup svetim mestima, učestvovanje u religijskim radnjama, dodirivanje svetih predmeta, kao i komuniciranje sa božanstvom podrazumeva prethodnu obrednu čistoću.

Blagdanski (praznični) obredi sociološki su relevantni jer omogućavaju analizu ponašanja vernika u tzv. svetom vremenu, kako prema svetim stvarima i ličnostima, rečju religijskoj tradiciji, tako i jednih prema drugima. Kritička oštrica usmerava se prema fenomenu komercijalizacije verskih praznika (Božić, Uskrs, Bajram, Hanuka), kada nekontrolisani konzumerizam nadvlada izvorno značenje proslavljanja, kao i verom motivisano darivanje i dobročinstvo prema ljudima u potrebi. Vrlo se slična ocena može dati i u slučaju hodočasničkih putovanja, koja poslednjih decenija sve više poprimaju karakteristike komercijalnog turizma, zamagljujući tako prvotne motive ove specifične religijske prakse i odlučujuće verski karakter pokloničkih putovanja. Cvitković nam nudi i svoju tipologiju hodočašća: 1. prema kriterijumu prostornoga značenja (mesna, regionalna/internacionalna, nacionalna i hodočašća univerzalnoga značenja); 2. prema kriterijumu hodočasničkog mesta (sveta mesta i sveti prostori); 3. hodočašća stopama svetaca; 4 . hodočašća na mesta važnih istorijskih događaja; 5 . hodočašća u mesta nastanka određenih religija; 6. hodočašća u mesta u kojima su živeli određeni sveci; 7. hodočašća u mesta koja donose sreću i ozdravljenje.

Obredi zahvalnosti obuhvataju karakteristične oblike zahvaljivanja u različitim religijskim tradicijama (izgovaranje molitvi, prinošenje životinjskih žrtvi, nuđenje hrane i pića), dok gozbeni obredi obuhvataju konzumiranje jela i pića i usmereni su na snaženje grupnog identiteta; mogu biti žrtveni i pogrebni, obavezujući, dopušteni ili zabranjeni, ali i podložni promenama i prilagođavanjima usled različitih istorijskih okolnosti. Kroz priču o kalendarima (gregorijanski, julijanski, jevrejski, muslimanski, indijski, kineski), Cvitković 
nas uvodi u tzv. kalendarske obrede, obično u bliskoj vezi sa pojedinim datumima tokom trajanja "religijske" godine ili drugim povodima (obeležavanje početka godišnjeg doba, molitve za izazivanje kiše ili uspešnost letine), među koje ubraja i novogodišnje obrede, koji su usko povezani s praksom darivanja najbližih. Obredi žrtvovanja, iako podrazumevaju prinošenje žrtvenog dara nadnaravnom biću, predstavljaju priliku za povezivanje članova religijske grupe, ali i jačanje osećaja pripadnosti zajednici. Konačno, ratni obredi mogu imati religijski karakter, bilo da se izvode pre (blagosiljanje oružja, polaganje zakletve, molitve za hrabrost, ratni plesovi), tokom (ratne propovedi, oprosti grehova, sveštenička bogosluženja) ili nakon ratnih sukoba (obredi za žrtve rata i poginule u ratu, komemorativni obredi, obredi zahvalnosti, obredi pokajanja, obredi očišćenja).

$\mathrm{Na}$ osnovu svega izrečenog, zaključujemo da je knjiga prof. Cvitkovića važan doprinos konstituisanju u balkanskim okvirima nedovoljno razvijene sociološke discipline - sociologije obreda ${ }^{1}$

\section{Encountering Others}

Knjiga Susretanje drugih (Religijski i konfesionalni identitet u BiH) (Cvitković 2013), sastavljena je od na engleski jezik prevedenih tekstova izlaganih na godišnjim konferencijama Jugoslovenskog udruženja za naučno istraživanje religije iz Niša, između 1998. i 2012. Dakle, rekapitulacija deceniju i po dugog druženja akademika Cvitkovića sa "junirovcima". Naslove referata diktirali su temati koje je uprava niškog naučnog udruženja svake godine određivala svim potencijalnim učesnicima. Nezavisno od toga, ovako objedinjeni na jednom mestu, rečito odslikavaju dijapazon autorovih interesovanja.

Kao vrsni poznavalac religijskih dešavanja na negdašnjim SFRJ prostorima, prof. Cvitković se posebno nadnosio nad dilemama prožimanja nacionalnog, konfesionalnog i religijskog identiteta u BiH. Koje se sociološke teme nameću pre drugih u ovoj knjizi?

1. Naglašeno (po)dokazivanje nacionalnog identiteta na balkanskim prostorima. Prenaglašeno isticanje nacionalnog identiteta, nacionalizam, kada nacionalni identitet postaje forma moderne, sekularne religije, najčešće kao rezultat reakcije na društvenu marginalizaciju nacionalnog identiteta. Neizgrađenu jedinstvenu jugoslovensku nacionalnu svest, kao jedan od uzroka raspada bivše Jugoslavije, autor sa zabrinutošću koristi da bi napravio paralelu u pogledu mogućnosti izgradnje jedinstvene "bosanske" nacionalne svesti.

\footnotetext{
${ }^{1}$ Koliko nam je poznato, pod ovim imenom je osamdesetih godina prošlog veka prevedena na slovenački jezik knjiga Žana Kazneva (Cazeneuve 1986).
} 
2. Odnos religije i konfesije prema naciji na Balkanu jeste model identifikacije religije i konfesije sa nacijom. Univerzalne religije (islam i hrišćanstvo), u uslovima teritorijalnog podudaranja sa pojedinim nacijama, doživljavaju se kao nacionalne religije (islam - bošnjaštvo; rimokatoličanstvo - hrvatstvo; pravoslavlje - srpstvo). Nacije se integrišu po religijskom i konfesionalnom predznaku, ali se neretko i religijski interes lako podvodi pod "nacionalni". Religija (hrišćanstvo i islam) i konfesija (rimokatolička, pravoslavna i islamska) javljaju se kao stabilizirajući element nacije. Nacionalni i konfesionalni simboli postaju simboli pripadnosti i odanosti zajednici.

3. Odnosi hrišćana i muslimana u Evropi i na Balkanu. Nepoznavanje istorije i učenja religije drugog između hrišćana i muslimana glavna je karakteristika njihovih međusobnih odnosa na evropskom kontinentu. Za jedan broj autora antiislamske orijentacije u teologiji, književnosti i političkoj publicistici, islam u Evropi jeste strano telo, religija stranaca tlačitelja i najveći neprijatelj zapadnog hrišćanskog sveta, muslimani u Evropi su samo islamizacijom “onesvešćeni” Evropljani, pa im se stoga brane dozvole za podizanje molitvenih domova. Isto tako, među islamskim ekstremistima favorizuje se stanovište o tome kako je hrišćane zahvatio proces sekularizacije, da narastaju novi religijski pokreti i da u sve većoj meri postaju podložni hedonističkom konzumerizmu. Mnogo je manje glasova koji pozivaju na dijalog, suživot i toleranciju pripadnika zajedničkog avramovskog nasleđa, na saradnju i preplitanje kulture i tradicije ovih dveju objavljenih religija. Ivan Cvitković je, međutim, beskompromisni kritičar hrišćanskih i islamskih ekstremista, ali i pomirljivi tumač Biblije i Kurana: bespogovorno otkriva loša mesta, tragajući za sličnostima u otkrivenim religijama.

4. Religijsko-konfesionalni identitet na granici. Tek se na "granici" susrećemo s pojavom Drugog, a do potrebe iskazivanja identiteta i dolazi u odnosu s Drugim. Što se više ide u dubinu rubnog, "graničnog", područja, to se više izražava potreba za identitetom $\mathrm{i}$ isticanjem simbola tog identiteta - to ima više veze s društvenim (katoličkim, muslimanskim, pravoslavnim) identitetom nego sa Bogom. "Granične" religijske zajednice čuvari su tradicija, u strahu od opstanka konzervativnije i opreznije u susretima s drugim vrednostima i identitetima. Prof. Cvitković kritički zaključuje da se džamije i crkve, od nekadašnjih "svetih mesta", pretvaraju, po Bosni i Hercegovini, u "kamene međaše". U rešavanju konflikata na granici, religijske zajednice trebalo bi da praktično pokazuju, ne samo na nivou naracije, da je nasilje među njihovim pripadnicima izdaja, a ne potvrda vere.

5. Odnos religija i religijskih zajednica prema globalizaciji. Proces globalizacije aktuelizovao je pitanje odnosa među religijama i religijskim zajedni- 
cama: hoće li globalizacija, u strahu od ujednačavanja načina života, podstaknuti politizaciju religija i religijskih zajednica u funkciji odbrane identiteta $\mathrm{i}$ preti li da ih ugrozi stvaranjem preduslova za nastajanje jedne "globalne religije" ili "religije svega" ili "globalističke" konfesije? Takođe, hoće li globalizacija dovesti do uspostavljanja "globalnih" standarda religijskih sloboda i sloboda svetonazora, čak pospešiti privatizaciju religije? Autor u religijskom nacionalizmu, tj. preteranom zanimanju za svoju religiju, koje ne ostavlja mesta za drugoga i njegovu religiju, prepoznaje prepreku na putu globalizacije. Sa svoje strane, pak, zauzima stajalište koje naziva relativizmom - prihvatanje svih svetonazora i religija u pluralnom sastavu vrednosti savremenog sveta i upoznavanje sa religijskom kulturom onih drugih.

6. Da li se desio "povratak" religija ili "povratak" religijama? U postsocijalističkom periodu na prostoru Balkana desila se promena institucionalne pozicije religije, dogodio se "povratak" religije u sferu javnosti, najpre u području politike i obrazovanja, a ne "povratak" građana religijama. Taj je povratak bio više motivisan željama za socijalnom promocijom nego religijskim razlozima. Namesto revitalizacije religije u smislu povećanja kvaliteta religioznosti desilo se osvajanje javnosti od strane verskih elita i religijskih institucija. Svepoželjna i društveno-politički sveprisutna religioznost dovodi do zaključka da je unosno biti religiozan, a ne vernik. Naglašenost kolektivne, a ne individualne religioznosti na još jedan način obeležila je "obnovljenu religioznost": religijska "obnova" odvijala se najpre unutar postojećih religijskih tradicija, "nasleđenih" ili "očinskih" religija, a ne kao "potraga" za "novim" religijama koja bi dovela do uspostavljanja novih kulturnih obrazaca; mogući razlog tome leži u prepletenosti religioznosti i nacionalnosti, o čemu je već bilo reči. Uporno je zaobilažen stav da religija i religijska zajednica spadaju, za državu, u privatnu sferu, te da je njen zadatak da brine o isključivo svetovnim interesima svojih građana.

Važna odlika naučnog opusa akademika Cvitkovića je nastojanje da sistematizuje zaključke svojih proučavanja u obliku proširivanja postojećih ili konstituisanja novih socioloških tipologija. Nekolicinu smo prepoznali i u sadržaju ove knjige.

1. Modeli odnosa prema drugim narodima:

a) Model izabranosti u odnosu na druge (neizabrane) narode

b) Model koji podstiče na netolerantnost

c) Model tolerancije koji podrazumeva uvažavanje "Drugoga"

2. Sociološki tipovi "povratnika" i preobraćenika:

a) "Tragači" - osobe koje su u traganju za duhovnošću završile u religioznosti, 
b) Konfesionalni "povratnik", bez religije,

c) Nacionalni vernik: religija kod njega ne igra gotovo nikakvu ulogu u svetovnom životu,

d) "Statistički" katolik / pravoslavni / musliman

e) Sezonski obraćenik

f) "Nedeljni hrišćani" i "džumski muslimani”

g) Isključivi obraćenik

h) Uključivi obraćenik

i) Pluralistički obraćenik

3. Tipovi hodočašća po kriterijumu prostornog značaja:

a) Hodočašća mesnog / lokalnog značaja

b) Hodočašća regionalnog značaja

c) Nacionalna hodočašća

d) Hodočašća univerzalnog značaja

4. Tipovi hodočašća po kriterijumu hodočasničkog mesta:

a) Hodočašće na svete planine, svete reke i sveta mesta

b) Hodočašće stopama svetaca

c) Hodočašće mestu za koje se veruje da se tu zbio značajan duhovni događaj

d) Hodočašće u mesta nastanka religije

e) Hodočašće u mesta života svetaca

f) Hodočašće u mesta koja donose sreću i ozdravljenja

Pažljivim iščitavanjem knjige Susretanje drugih izdvajamo najvažnije autorove poruke:

1. Uz svo uvažavanje islama (i Islamske zajednice), katoličanstva (i Katoličke crkve), pravoslavlja (i Srpske pravoslavne crkve) u razvoju nacionalne svesti Bošnjaka, Hrvata i Srba, zar danas neko mora verovati i biti musliman, katolik ili pravoslavni da bi bio Bošnjak, Hrvat, Srbin?

2. Nacionalni, religijski i konfesionalni identitet ne predstavljaju ništa loše, sve do onog trenutka kada se nečiji identitet počinje stvarati na temelju ugrožavanja drugog / drugih identiteta.

3. Religija ne može biti osnova za konstituisanje moderne nacije.

4. Religijski pluralizam ne mora dovesti do "potkopavanja" religije. Suprotno tome, "istorijski zasnovane" religijske zajednice, miljenice države i njenih finansija, vode spokojnom životu religijskih vođa, ali i slabljenju participacije u religijskom životu.

5. Samo neskloni religijskom pluralizmu uzimaju broj kao kriterijum za položaj neke religijske zajednice u društvu. Religija nije stvar geografske rasprostranjenosti, niti "broja vernika”, nego pouka i misija. 
6. Religijske slobode su ključno pitanje na kojem se proverava demokratičnost nekog društva. U okviru toga, svakako, na prvom mestu je odnos prema religijskim manjinama. Svakoj religiji i religijskoj zajednici treba omogućiti delovanje.

7. Na religijskim zajednicama je da istraže i ocene da li je uspostava bliskih odnosa između političkih i religijskih elita i političko jačanje religijskih institucija, nakon urušavanja socijalizma, vodilo duhovnom gubitku religija ili njihovom jačanju.

8. Bogoslovi o religiji najčešće govore u obliku idealnog modela, a sociolozi u obliku stvarnog modela, kakav on u stvarnom životu jeste.

9. Teološko-filozofska pitanja da li Bog postoji, sociolog religije zamenjuje pitanjem: koliko to što čovek (ne)veruje u (ne)postojanje Boga utiče na njegove društvene odnose? Odnosno, sociologa religija interesuje samo u društvenom kontekstu.

10. Karakter savremenih hodočašća kreće se u rasponu od izvornog duhovnog čina do "religijskog" turizma.

\section{Socijalna naučavanja u religijama}

Jačanje religijskog senzibiliteta u bližoj budućnosti na Balkanu kontinuiran je proces u koji će tradicionalne crkve i verske zajednice morati da ulože mnogo više energije nego što su to činile do sada. Ide li pod ruku zalaganje za očuvanje tradicionalnog obrasca nacionalnog i kulturnog identiteta, na kolektivnom, i obogotvorenje kroz življenje sa drugima i za druge u lokalnom hramu, na individualnom planu, sa manje-više postignutom političkom saglasnošću javnog mnjenja o potrebi integrisanja u evropske tokove?

Sociolozi religije svetskog formata procenjuju da "što se društvo pomera bliže Evropi, biće pod većim uticajem evropske sekularnosti”, odnosno da verska zajednica u sudaru sa dinamičnom konkurencijom pluralističke situacije ima tri opcije: "da pruža otpor, da se povuče ili da se upusti u odnos sa pluralizmom” (Бергер 2010: 354-55). Prve dve mogle bi se okarakterisati neotradicionalizmom, a na treću se računa, saglasno očekivanjima da crkva nije suprotstavljena društvu. Na evropskom religijskom tržištu, sa strogim pravilima igre, sve su crkve i verske zajednice podvrgnute kompetitivnosti i samo od njihovih pojedinačnih sposobnosti i zalaganja zavisiće uspeh u verskom delovanju.

Tako smo, recimo, u jednom ranijem radu (Тодоровић 2014) upozorili kako Srpskoj pravoslavnoj crkvi tek sleduje sveobuhvatan aggiornamento, po uzoru na katolike. Predstoji joj nadmetanje u otvorenom evropskom kul- 
turnom i religijskom okruženju, a ne samo deklarativna podrška tekovinama koje zapadna civilizacija promoviše u svom širenju prema Istoku (Биговић 2011). Željenoj religijskoj rekonkvisti, međutim, neće doprineti samo uznapredovala svest verništva o neophodnosti liturgijskog zajedništva već i konkretni kapaciteti pravoslavlja da odgovori na izazove današnjice. Pogleda uprtog u evropsku budućnost, mladi ljudi okrenuće se religijskom obrascu života ukoliko prepoznaju redefinisanu javnu ulogu i oblike dosadašnje pastoralne delatnosti SPC u srpskom društvu. Ona bi trebalo da bude glasni i nepristrasni zagovornik verskih rešenja različitih civilnih problema, a ne, kako je to najčešće bivalo do sada, objekat neprimerenih i uskogrudih svojatanja političkih aktera na medijskoj sceni.

U sferi javne delatnosti ove promene obuhvatale bi: 1. odustajanje od zapaljive nacionalne retorike zasnovane na šovinizmu (fanatizam i netrpeljivost prema pripadnicima manjinskih naroda i etničkih grupa); 2. podršku vernicima za učestvovanje u političkom životu (prožetost hrišćanskim duhom kao prednost u delovanju u javnoj službi); 3. promociju srpsko-pravoslavne kulturne baštine kao doprinos obogaćivanju evropske kulturne tradicije, ali i upoznavanje domaćeg verništva sa kulturnim dostignućima drugih hrišćanskih naroda; 4. saradnju sa civilnim sektorom (odbranu dostojanstva čoveka i osnovnih ljudskih prava: prava na život, slobodu savesti i versku slobodu, socijalnu pravdu i mir, predupređivanje diskriminacije, ksenofobije i nasilja); 5. preispitivanje temeljnih vrednosti i etosa sadašnjice (promociju socijalne pravde, borbu protiv korupcije i kriminala, odbacivanje različitih oblika nejednake raspodele društvene moći, preispitivanje dometa tržišne privrede zasnovane na neobuzdanoj konkurenciji); 6. podsticanje socijalno-etičke rasprave o pravednosti ekonomije i kritiku anomalija potrošačkog društva (gramzivost za zaradom, ljudsku pohlepu, nejednaku raspodelu društvenih dobara); 7. podizanje svesti o važnosti zaštite životne sredine; 8. filantropiju, zadužbinarstvo i humanitarni rad; 9. afirmaciju hrišćanskih vrednosti u privrednoj delatnosti (poštenje, savestan rad, solidarnost, odnos prema radnoj sredini).

U sferi pastoralne brige promene bi se odnosile na: 1. učestvovanje u teološkom i crkvenom dijalogu na međunarodnom nivou u telima ekumenskog pokreta; 2 . smanjivanje antikultne retorike naspram malih verskih zajednica $i$ umanjenje iracionalnog straha među građanima od negativnog delovanja sekti i kultova; 3. saradnju i zajednički nastup sa ostalim hrišćanskim crkvama i denominacijama u javnim istupanjima; 4. podršku omladini u sticanju institucionalnog visokog obrazovanja; 5. uzdizanje higijenskih navika u porodici i prevenciju u zaštiti od polnih bolesti; 6 . afirmaciju ravnopravnosti polova u porodičnim odnosima; 7. buđenje preduzetničkog duha među vernicima i 
pružanje elementarne pomoći u podsticanju samozapošljavanja; 8. smanjivanje distance između sveštenstva i vernika i evangelizaciju izvan verskih hramova, uz aktivnije učestvovanje paroha u rešavanju gorućih problema tranzicionih gubitnika na lokalnom nivou (siromaštvo, nezaposlenost, bolest); 9 . senzibilitet za nevolje ranjivih manjinskih grupa (etničkih, rodnih).

Na ovaj način stupamo na područje socijalnog učenja verskih zajednica. Promišljanje aktuelnih društvenih pitanja, sa jedne strane, odgovor je na potrebu dijaloga religija i konkretnih crkava sa svetom, odnosno redefinisanja mesta religijskog u savremenim društvenim okolnostima, a sa druge, način teološkog osmišljavanja procesa evangelizacije i pastoralne delatnosti u javnom životu, naročito postkomunističkih društava obeleženih tranzicijskim specifičnostima. Racionalno i realno suočavanje sa mnogostrukim vidovima poremećenih međuljudskih odnosa i patnjama pojedinaca i društvenih grupa ne vrhuni više u molitvi i propovedi. Paleta "znakova vremena" gotovo je nepresušna: poslovanje "mimo" zakona i njihovo nepoštovanje, privredni i organizovani kriminal, borba protiv korupcije, pohlepa za gomilanjem materijalnih dobara, jaz između bogatoga Severa i siromašnog Juga, sukobi rada i kapitala, položaj i prava radnika u svetu rada, pravo na sindikalno organizovanje, održivi razvoj, zaštita životne i radne sredine, objektivno medijsko izveštavanje, konzumerizam i potrošačko društvo, učestvovanje vernika u političkom životu, pravedna raspodela svetskog bogatstava, solidarnost sa zemljama u razvoju, zaštita bolesnih, odbačenih i zaboravljenih, nejednake mogućnosti ostvarivanja prava na obrazovanje za sve, nezaposlenost, loš položaj penzionera, jednoroditeljske porodice, alkoholom i drogama uslovljeno porodično nasilje, istopolni brakovi, trgovina ljudima i decom, bioetika, izazovi života u digitalnom dobu, pravedan razvoj informacionih tehnologija, očuvanje i promocija mira, osuda terorizma, kritika trke u naoružanju, opasnost od nuklearnoga i drugog oružja masovnog uništenja, pitanje stranih radnika i migranata, utvrđivanje istorijskih istina i borba protiv istorijskog revizionizma, dijalog i pomirenje među narodima... Na Balkanu u tome prednjači Rimokatolička crkva, ${ }^{2}$ a kaskaju sa uključivanjem Srpska pravoslavna crkva $^{3}$ i Islamska zajednica.

\footnotetext{
${ }^{2} \mathrm{Na}$ Katoličkom bogoslovnom fakultetu u Zagrebu 2000. godine formirana je Katedra socijalnog nauka Crkve (Baloban 2004: 1020). U okviru Hrvatske biskupske konferencije u novije vrijeme deluje i Centar za promicanje socijalnog nauka Crkve (Vranješ 2010: 459). Papsko veće za pravdu i mir objavilo je Osnove socijalnog učenja Katoličke crkve (Papsko veće za pravdu i mir 2006).

${ }^{3}$ Prevedeni su Osnovi socijalne koncepcije Ruske pravoslavne crkve (Руска православна црква 2007).
} 
Od sposobnosti religijskih zajednica kao institucija da deluju u laiciziranom svetu, odnosno od spremnosti da prošire katalog tema o kojima misle i javno govore, ali se i više angažuju u ublažavanju i prevazilaženju množine socijalnih izazova, zavisiće jednim delom i njihovo buduće opstajanje u 21. veku.

$$
* * *
$$

Knjiga prof. Cvitkovića Socijalna naučavanja u religijama (2007) pruža detaljan uvid u stanovišta velikog broja religijskih zajednica o tradicionalnim društvenim fenomenima (porodica i brak, moral, zdravlje, ishrana, siromaštvo), ali i o onim koje ljudska civilizacija smatra izazovnim poslednjih decenija (civilno društvo, demokratija, ljudska prava, nacionalni identitet, socijalni rad, zaštita životne sredine, konflikti i nasilje, verski turizam). Oslanjajući se na nesumnjivu ličnu erudiciju, autor najpre oslikava glavna stajališta o svima njima sadržana u najpoznatijim svetim spisima (Stari i Novi zavet, Kur'an, Bhagavad-Gita, Upanišade, Talmud), ilustrujući ih prebogatom religijskom praksom iz najrazličitijih perioda razvoja ljudskog roda, da bi na kraju podvrgao kritičkoj sociološkoj oštrici sve one otvorene i skrivene protivrečnosti sadržane u sukobu pisane reči i istorijskom delovanju. Cvitković, zapravo, pretresa odnos dogmi, vrednosti, normi i praksi različitih religija prema najvažnijim društvenim pitanjima i propituje (ne)postojanje istinskog potencijala u svetskim verama za suočavanje sa njima, kao i njihovo razrešavanje. Kad god je u prilici, svoje stavove eksplicira na primeru religijske raznolikosti bosansko-hercegovačkog društva.

Neki od davno zauzetih stavova u svetim knjigama, poput onih o braku, porodici i rodnim odnosima, predstavljaju opredeljenja koja je najteže podvrgnuti prevrednovanju. Iako iz godine u godinu prisustvujemo izjednačavanju prava muškaraca i žena u svakodnevici, čak neuobičajenoj blagonaklonosti javnog mnjenja prema uzdizanju žena u društvenoj hijerarhiji, ${ }^{4}$ njihov položaj najteže je podložan izmeni u religijskim spisima i retoričkim istupima crkvenih velikodostojnika.

Biblijskom scenom dominira ponižavajući položaj žene u većini ključnih situacija. "Veliki je jad, sramota i ruglo kad žena uzdržava muža svoga" (Stari zavet) (Cvitković 2007: 112). Prema Novom zavetu, žena je vezana za svog muža sve dok on živi (Cvitković 2007: 121), uz posebno insistiranje na instituciji nerazrešivosti braka. U Talmudu se upozorava: "Brzo, ako kupuješ zemlju, polagano - ako uzimaš ženu. Siđi stepenicu niže te uzmi sebi ženu" (Cvitković 2007: 105). Kod Jevreja postoji i molitva: "Blagoslovljen budi,

\footnotetext{
${ }^{4}$ Poslednji je takav primer nedavno imenovanje Katerine Sakelaropulu za prvu predsednicu Grčke.
} 
Bože naš, jer me nisi učinio ni poganinom, ni ženom, ni neznalicom" (Cvitković 2007: 132). Po Kur'anu, Bog “žene stvara, da se uz njih smirite” (Cvitković 2007: 102). Hinduizam je naglašavao ženinu podređenost muškarcu: u detinjstvu ocu, u zrelosti mužu prema kome se treba odnositi kao prema Bogu, a u starosti sinovima (Cvitković 2007: 111). Hadisi lezbijstvo ubrajaju u prostituciju i razvrat (Cvitković 2007: 130). Teme poput kontracepcije, pobačaja, veštačke oplodnje, predbračnog seksa, istopolnih brakova, ali i rukopoložanje žena, još zadugo neće zadobiti "milost” teologa inih religijskih provenijencija.

Pažljivo posmatran, ambivalentan je i odnos raznih religijskih učenja prema siromaštvu. Judaizam na njega gleda kao na dar Božji ("Blago bogatašu koji će se naći nekažnjen”), dok u Bibliji nema status najvećeg dobra (ne može biti Isusov učenik onaj ko se "ne odriče svega svoga imanja", ali i "kako je mučno ući bogatašu u kraljevstvo Božje”). U Kur'anu se navodi: “Teško svakom klevetniku podrugljivcu, koji blago zgrće i broji ga, misleći da će blago njegovo vječnim učiniti njega!” (Cvitković 2007: 140). Ni po Upanišadama niko ne može očekivati da bogatstvom dosegne besmrtnost. Ipak, socijalna stratifikacija se opravdava (u budizmu ne, jer je zasnovan na odbacivanju indijskog kastinskog sistema). Siromasima se u Jevanđelju po Luki propoveda "Radosna vest", njihovo je "kraljevstvo Božje", ali se u Jevanđelju po Marku kaže sledeće: "jer tko ima, dodat će mu se, a tko nema, oduzet će mu se i ono što ima" (Cvitković 2007: 138). Bogatstvo valja trajno sticati i paziti da se ne pretvori u gramzivost, koja je jedan od smrtnih grehova. Protestantizam naglašava štedljivost i radinost, a oni su siguran put u imućnost. Konačno, manje je vrednovanje religije u ekonomski razvijenim zapadnoevropskim zemljama (Švedska, Danska, Norveška, Finska). Sa druge strane, nalaže se bogatima da pomažu siromašne. "Svake treće godine židovi su desetinu trebali ostaviti levitima, došljacima i siromašnima, a zemljoradnik rub svog polja ili voćnjaka siromašnima" (Cvitković 2007: 141). Jer, siromaštvo može voditi gubitku vere (hadis Muhamedov) (Cvitković 2007: 145).

Ako je nastalo kao "kraljevstvo siromašnih" i ako se od pamtiveka poistovećivalo sa marginalizovanima, kako od hrišćanstva očekivati da podrži svetska nastojanja za iskorenjivanjem nemaštine, bolesti i nepismenosti, posebno one strukturno uslovljene i podržane? Ako su besperspektivni potencijalno religiozniji i "ako nevolje vode u bogomolje" (Šušnjić), zašto bi islam stao na stranu zagovornika iskorenjivanja bednih i potrebitih na afričkom i azijskom kontinentu, iako u njima predstavlja dominantan religijski obrazac? Može se tome dodati i spremnost pojedinih verskih vođa da listom podrže autoritarne političke režime kojima su daleko od pameti ideje o jednakosti svih podani- 
ka. Ono u čemu se jesu religijske zajednice dokazivale kroz istoriju bila je karitativna delatnost (spoljašnja i unutrašnja pomoć u nevolji) i solidarnost (izdvajanje od sopstvenih primanja), no ona je vodila tek ublažavanju stradalničkog položaja pojedinih društvenih slojeva, nikako temeljnoj promeni postojećeg statusa.

Verski angažman u sferi socijalnog ne završava se samo brigom o najsiromašnijima. Religijske zajednice mogu dići glas i za armiju nezaposlenih u svetu, ali i za one čije dostojanstvo izrabljuju u modernom svetu rada. Bez socijalnog su osiguranja milioni "radnika na crnom", kao i migranti svih boja i rasa. Iako današnji svet počiva na kapitalističkom privređivanju, mnogo je povoda kada bi se najveći religijski autoriteti usprotivili nehumanim zakonima tržišne privrede i privatnog kapitala u svetskim razmerama (surovi uslovi rada, dečiji rad).

Može li se očuvati i unaprediti ugled i dostojanstvo religijskog faktora u trećem milenijumu kroz kvalitetniju saradnju sa tzv. civilnim sektorom? Jesu li moguće različite religijske laičke inicijative u pravcu zaštite ljudskih prava i, recimo, obezbeđivanja ravnopravnosti inih manjina (etničkih, verskih, političkih, kulturnih, rodnih, seksualnih)?

Hrišćanstvo je zagovaralo ideju jednakosti od svojih prapočetaka ("Nema tu Jevreja, ni Grka, nema Boga ni gospodara, nema muškoga roda, ni ženskoga; jer ste svi jedno u Hristu Isusu" /Gal. 3, 28/), dok se ona u islamu naziva "univerzalno bratstvo" i najočiglednije primećuje u praznično vreme. No, prava jednakost ogleda se u slobodi izbora, za koju se očekuje da bude podržana od strane svih religijskih autoriteta. Najpre je to sloboda da se veruje ili ne veruje i sloboda da se izaberu, ispovedaju i praktikuju religijska uverenja bez ograničenja. Zatim da se ona garantuju zvaničnim zakonskim propisima, da bi se konačno ovaplotila u svakodnevnom životu kroz ideju tolerancije.

Mogu li ruku pod ruku religijski i nacionalni identitet, posebno u multikonfesionalnim i multietničkim sredinama, kakva je $\mathrm{BiH}$, pita se naš autor? $\mathrm{U}$ davnašnja vremena jevrejska tradicija svedočila je o Jahveu i izabranom narodu. Novi zavet prihvatio je pojedinca nezavisno od njegove etničke pripadnosti: katoličanstvo je kasnije postalo nadnacionalno (ne nužno i anacionalno), a pravoslavlje je prigrlilo jedinstvo nacionalne i religijske zajednice. Islam i protestantizam su u principu ravnodušni prema naciji. "Treba li Bosni i Hercegovini puno religija ili puno vjere? Ili, možda, manje i jednog i drugog? Ili je potrebno više pomirenja i povjerenja među nacionalnim i konfesionalnim identitetima? Ne renesansa kršćanstva i islama, već multireligijske Bosne i Hercegovine" (Cvitković 2007: 92). Najveći doprinos religijske i nacionalne grupe, skupa sa civilnim sektorom, ostvarile kada bi promovisale život jednih 
sa drugima. Dakle, ne jedni pored drugih (što predlaže multikulturalizam), već jedni sa drugima (što je ideja vodilja interkulturalizma); nikako jedni protiv drugih (kako je, inače, bivalo u nedavnoj prošlosti) (Todorović 2019).

Šta tek reći o mogućnostima da religije u budućnosti budu nezamenljivi promoteri dijaloga i pomirenja, posebno na konfliktima bremenitom balkanskom tlu! Istorija verskih progona, neretko pravdanih misionarskim nastojanjima, večito je podsećanje na vekovno iskustvo nasilja pod religijskim znamenjem. Ko želi, pronaći će u istim religijskim knjigama zapovest "Ne ubij!”, kao i poziv na sveti rat. Od osude nasilja, zalaganja za mirno rešavanje konflikata i molitvi za mir u svetu efikasnijim nam se čini versko zalaganje za vaspitanje mladih naraštaja za izgradnju kulture mira. (OUN je 1999. godine usvojila Deklaraciju o kulturi mira.) Ona bi se temeljila na preduzimanju interreligijskog dijaloga i zalaganju svih religijskih zajednica za rušenje svekolikih religijskih predrasuda (hrišćani, recimo, učestvovanjem u ekumenskom pokretu), boljem upoznavanju sopstvenih vernika sa religijskom kulturom iz bližeg i daljeg okruženja, javnim obračunavanjem sa ekstremistima u sopstvenim redovima, zalaganjem za vladavinu prava građana svih religijskih i nacionalnih pripadnosti i sl. U tome nedvosmisleno mogu računati na pomoć nevladinog sektora.

Ekologiju mnogi nazivaju i najvećim religijskim izazovom u XXI veku (Kristić 2018). Iako abramovske religije podučavaju božansko stvaranje ovozemaljskog sveta, a večni život vezuju za "onaj svet”, znakovi svetske ekološke krize probudili su savest religijskih autoriteta. Uništenje životne sredine od strane čoveka (klimatske promene, degradacija flore i faune, zagađenje zemlje, vazduha, vode i hrane, bespoštedna seča šuma) nagnalo je najumnije verske glave da promisle svetost prirode i odgovornost ljudskog roda prema dolazećim generacijama. Takođe, mogli bi doprineti oblikovanju ekološke etike i razvijanju ekološke svesti kao oblika preventivnog delovanja u cilju održavanja ravnoteže između čoveka i prirode. Pored osnivanja religijskih pokreta za zaštitu prirode, sledbenici različitih religija mogli bi da se pridruže sve glasnijim prozivkama transnacionalnih kompanija i nezasitog kapitalizma uopšte za destrukciju prirode koja se pravda konzumerizmom i neumerenim tehnološkim razvojem.

\section{Religije suvremenoga Svijeta}

Iza naslova Religije suvremenoga svijeta (2005) krije se sociološki, donekle i enciklopedijski, presek današnjih religija i precizna analiza njihovih suštinskih odrednica. Krasi je uporedni pristup u analizi i elaboraciji savremenih religija, prema ključnim sastavnicama svake od njih, kao što su: nastanak, 
rasprostranjenost, učenje, etički segment, običaji i ritualne prakse i njihovi savremeni pogledi.

U knjizi je dat jasan pregled osnovnih pitanja koja se tiču, kako ih akademik Ivan Cvitković naziva, “živućih” religija, danas prisutnih na zemljinom šaru. Čine je predavanja održana studentima novinarstva na Fakultetu političkih nauka u Sarajevu tokom zimskog semestra školske 1998/99. godine, zbog čega slobodno može poslužiti kao obavezan priručnik i studentima drugih društveno-humanističkih disciplina. Pokatkad suvoparne osnovne podatke o savremenim religijama autor nadopunjuje lucidnim zapažanjima i objašnjenjima.

Publikacija započinje opštim uvodom u stanje religije u savremenosti, uokvirujući najpre fenomen "sekularizacije". Velike debate oko sekularizacijske teze sve više se nadovezuju na stav da je ona bila mit (Hamilton 2007). Pisac u analizi izdvaja krucijalne ideje vezane za konfiguraciju i mapiranje savremenih religija (na početku trećeg hiljadugodišta), kao što su povratak religiji, aktuelna religijska kretanja, adaptacija religija novim kulturama i običajima i sl. Akademik Cvitković, pored izdvajanja društvenih faktora vezanih za pojavu i razvoj savremenih religija, podvlači "prodor" hrišćanstva u tzv. Treći svet, ali i islama i istočnjačkih religija i iz njih nastalih novih religijskih pokreta, na Zapad. Ono što daje karakterističnu notu religijskoj situaciji savremenoga sveta jeste "jačanje uloge religije i religijske zajednice u razvijanju osećanja zajedništva, pripadnosti, identiteta. Tempo suvremenog života potisnuo je čovjekovu emocionalnu, intelektualnu i duhovnu dimenziju, te se nadoknada traži i u religijskoj pripadnosti” (Cvitković 2005: 21). Uloga religije u društvu iscrpljuje se u tome kakve osnove religija nudi za izgradnju ličnog i grupnog identiteta (Šušnjić 1998).

Knjiga Religije suvremenoga svijeta podeljena je u deset tematskih celina (Pojam religije; Religije u Indiji; Religije dalekog Istoka; Suvremene monoteističke religije; Sikhizam; Religije u Africi; Američke religije; Religije Oceanije; Novi religijski pokreti i Što od novinara traži profesionalni moral?).

Ivan Cvitković analizu počinje tako što definiše religiju kao "vjerovanje u Nadnaravno i sveto izraženo religijskim običajima, obredima i simbolima o kojima se skrbe religijske organizacije i religijsko vođstvo, i koje sljedbenike date religije opskrbljuju moralnim definicijama" (Cvitković 2005: 37). Nadalje se slikovitim i preciznim stilom izražavanja, konkretno i pragmatično sumira suština postojećih religija.

Knjiga obiluje brojnim podacima, uvidima, analizama i argumentima, koji su rezultat napornog i dugogodišnjeg istraživačkog rada. Posebnu dragocenost za sociologiju religije predstavlja autorov predan komparativni rad i sposobnost da nam na malo prostora ponudi koncizne i koherentne informacije o 
svetskim religijama, kako iz neposrednog okruženja, tako i na najudaljenijim tačkama ekumene. Bez obzira na to da li je reč o hinduizmu kao kulturnoj tradiciji, đainizmu kao religiji i filozofiji, suštini budističke etike, podacima o hrišćanstvu i širenju protestantizma ili, pak, o značaju i enigmatičnosti novih religioznih pokreta, akademik Cvitković analitički prikazuje višeslojne teme koje su predmet njegovih interesovanja.

U sklopu obrađenih religijskih sistema značajan prostor posvećuje se odnosu prema drugim pripadnicima zajednice. Svaka religija sadrži set moralnih postavki, sa ciljem da odredi svojim vernicima šta je dobro, a šta loše (ili nepoželjno) ponašanje, odnosno da ih uputi kako treba (ili ne treba) da se ponašaju (Cvitković 2005: 36).

Knjiga se završava odgovorom na pitanje sadržano u naslovu desetog poglavlja. Akademik Cvitković upućuje sažete smernice budućim novinarima o tome kako treba da pripremaju priloge o religijama; zapravo vešto ispisuje etički kodeks novinara koji izveštavaju o pitanjima iz religijskog domena. Autor podvlači da novinar treba da bude pobornik slobode mišljenja, savesti i veroispovesti, da treba da se zalaže da država svojom politikom omogući svim religijama i religijskim zajednicama jednak pristup medijima. Novinar treba u svom radu da afirmiše nepristrasnost prema sopstvenoj religiji, ali i da vodi računa da ne zadire u religijsku "osetljivost" publike. Posebno se potcrtava obaveza novinara da se nikada ne upušta u diskusije oko pitanja (ne)istinitosti nekog religijskog učenja, niti da se bavi “ocenjivanjem" koja je religija "najbolja". Uz odlučno nabrajanje normi koje novinar ne sme sebi da dopusti, zaključuje se da "novinar nikad neće izazvati, ni poticati na izazivanje, raspirivanje ili podržavanje vjerske diskriminacije, netrpeljivosti, nasilja, mržnje i razdora".

Uz već više puta potenciran osoben autorov stil prezentacije etičkih učenja savremenih religija, knjigu odlikuje naveden etički kodeks novinara za izveštavanje o religijama i povodom religija, kao i pregled bogate bibliografije iz oblasti sociologije religije. Time je profesor Cvitković ostavio neizbrisiv trag u bosansko-hercegovačkoj akademskoj zajednici, ali sigurno i izvan njenih granica.

\section{Sociologija religije}

Knjiga Sociologija religije (2007b) najpopularnije je delo akademika Ivana Cvitkovića. Doživela je četiri izdanja (1995, 1996, 2004, 2007), najpre zahvaljujući interesovanju studenata za sociološko proučavanje fenomena religije.

Čine je četiri tematske celine, kroz koje je umešno i bogatim jezičkim izrazom prikazan sociološki pristup religijskom fenomenu. Na samom početku, 
autor daje sociološko određenje pojma religije, uvažavajući njegove ključne sastavne elemente (verovanje u Nadnaravno, pojam svetog i profanog, verovanja, obredi i običaji, simboli religije, religijske organizacije i institucije, religijska vođstva, religija kao izvor morala).

Deskripcijom fenomena "povratak religijama", između ostalog, profesor Cvitković podvlači da je u drugoj polovini dvadesetog veka "biti religiozan" podrazumevalo političku neangažovanost. No, religioznost početkom trećeg milenijuma (posebno u Bosni i Hercegovini) upravo uključuje politički angažman. Religija je kompleksan društveni fenomen i dinamična kategorija koja se stalno razvija, kao što se uostalom razvija i interakcija politike i religije (Fox 2018). Kontekstualizacija društvene krize stvara pogodan temelj "za bitne pomake u već uspostavljenoj religijskoj situaciji, uključujući i mogući zaokret od sekularizacije ka revitalizaciji religije i od revitalizacije religije ka desekularizaciji i kontrasekularizaciji” (Vrcan 1986: 127). Do "povratka svetog" (Bell 1977) i obnove religije dolazi u kraćim ili dužim periodima temeljnih društvenih kriza. Posebnu vrednost knjige Sociologije religije predstavlja konkretna obrada socioloških indikatora "povratka" religijama, u koje Cvitković ubraja: 1. povećanu participaciju u religioznim aktivnostima, 2. porast publicistike religijskog sadržaja, 3. naglašavanje religijske pripadnosti, 4. nastanak novih religijskih pokreta, 5. povratak religije u škole, 6. uvođenje religijskih zajednica i institucija u politički život i 7. traženje oslonca u religijskih zajednicama od strane vlada i stanovništva radi postizanja ličnog autoriteta, što dovodi do državne (zlo)upotrebe religija i religijskih zajednica.

Kada se govori o "povratku" religijama u postsocijalističkim društvima, naglašava se da se ne radi samo o "povratku" religiji, već i o njenoj "deprivatizaciji” (Cvitković 2007b; Cacanoska 2011). Cvitković jasno potcrtava pozitivne i negativne posledice ove pojave. Sa jedne strane, revitalizacija religije propraćena je obnovom nekih nacionalnih osećanja i interesa (Šušnjić 1998), sa druge, društvena poželjnost religijske pripadnosti može prouzrokovati svođenje religije na nacionalnu tradiciju, jer se uzima kao najvažniji činilac nacionalnog identiteta. Cvitković naglašava da je u zajednicama u kojima su vladajući modeli identifikacije religije (konfesije) i nacije "povratak" religiji značio i "povratak" naciji, i obrnuto. Postsocijalistički "povratak" religioznosti sociološki se očitavao u formalizovanoj religijskoj praksi, zaključuje autor.

Druga tematska celina posvećena je problemima sociologije religije koji proizilaze iz određenja predmeta sociologije religije, sa posebnim akcentom na sociološkim determinantama religioznosti, maestralno skiciranom uticaju religija u društvu i prezentacijom ključnih pitanja koja obuhvataju metode sociološkog istraživanja religija. Akademik Cvitković izučava same "religije 
u dejstvu" (Redklif-Braun 1982) i sa lakoćom nabraja funkcije religije u društvu: integrativna, dezintegrativna, religija i socijalna stratifikacija, religija i interakcija, kompenzacijska uloga religije, privredna, etička i interpretativna funkcija religije u društvu.

U srž sociologije religije ulaze i različite tipologije vezane za proučavanje religijskog fenomena. Tipologija religijskih organizacija, tipologija religijskih vođa, tipologija vernika i tipologija odnosa između religijskih zajednica i države - čine set pitanja koja izazivaju najveću studentsku pažnju. Sinte$\mathrm{zu}$ istorijsko-sociološkog i filozofskog pristupa problemu tipologije verskih vođa profesor Cvitković predstavlja kroz sledeće varijetete: prorok (poseduje izvornu harizmu, govori u božje ime), mesija (božansko biće) i sveštenik (profesionalac, "nameštenik" religijske zajednice, njen "ceremonijal majstor"). I tipologizacija vernika konkretno je teorijski utemeljena i dopunjena bogatim iskustvenim materijalom.

Istraživanje religijskog fenomena nalaže korišćenje kvantitativnih i kvalitativnih metoda, što Cvitković vispreno preduzima u svojoj knjizi (Spickard 2007). Podaci se najpre prikupljaju anketom, intervjuom, posmatranjem i analizom sadržaja, zatim se dalje obrađuju i iz njih izvode valjani zaključci sa ciljem potvrđivanja postavljenih hipoteza ili odgovora na istraživačka pitanja. U tom smislu ne treba ispustiti iz vida komplementarnost istraživačkih metoda kao važan segment $u$ istraživanju tema koje se direktno ili indirektno odnose na religiju. Zapravo, sociolog religije treba da se koncentriše na empirijske realnosti povezane sa religijom, onako kako se manifestuju u različitim delovima sveta (Davie 2007).

Izrazito bogatstvo teorija i empirijskih iskustava pokazano je u poslednjoj tematskoj celini, posvećenoj sociološkim aspektima odnosa društvo-religija. Aktuelna pitanja koja se nameću savremenom društvu obuhvataju: društvene konflikte, privredu, politiku, demokratiju i ljudska prava, naciju, brak, ravnopravnost žena, globalizaciju, ekologiju i dr. Njihovim razmatranjem Cvitković ostaje na tragu Zigmunta Baumana, koji je govorio da sociologija treba da se nalazi u trajnom "otvorenom dijalogu sa svakodnevnim životom". Raspravom o sekularizaciji kao mitu ili stvarnosti, kao i elaboracijom marksističke teorije o religiji, a zatim i tipologijom ateizma, Cvitković priprema prostor za završnu debatu o budućnosti religije. Prisutne teorijske kontroverze razvrstane su u tri modela i otvaraju raznovrsne pristupe u promišljanju teme. Prema prvom, religija je prirođena čovekova potreba, koja ima svoju prošlost, sadašnjost i budućnost; drugi model se iscrpljuje u pokušaju da se tradicionalne religije zamene nekom novom religijom, dok treći model zagovara kraj religije. Akademik Cvitković neprimetno, ali vešto vodi studente kroz bogate 
teorijske fundamente prisutne vekovima koji promišljaju prošlost, ali i futuristički uokviruju religije. Način izlaganja poslednje tematske celine podjednako je inspirativan kako zbog postavljenih pitanja, tako i zbog ponuđenih odgovora. Udžbenik Sociologija religije razvija proaktivnu ulogu studenata u promišljanju mnogobrojnih tema povezanih sa različitim religijama. Iako prvi put publikovan pre tačno 25 godina, konceptom i obradom postavljenih tema zadržao je aktuelnost i ostao nezaobilazno studentsko štivo i u novom milenijumu.

Brz i često skokovit društveni razvoj, posebno tema digitalizacije i novih informacijskih tehnologija, postavlja niz izazova pred sociologiju religije. Nadolazeće teme mogu se analizirati jedino čvrstim povezivanjem sa prethodnim razvojnim etapama sociologije religije, koje prof. Cvitković izvanredno obrađuje u Sociologiji religije.

Ono što njegovo delo čini posebnim je stil pisanja. Na taj se način nadomešta nerazumljivost kao jedan od čestih propusta u sociološkoj literaturi koji je Knoblauh nazvao njenim lošim imidžom (Knoblauh 2004). Autorov sociološki jezik je bogat, razgovetan i besprekorno precizan što je knjigu Sociologija religije učinilo prihvaćenom podjednako od strane naučne javnosti, studenske populacije i najšire publike.

\section{Religija u zrcalu teorija}

Religija u zrcalu teorija knjiga je novijeg datuma (2016), u kojoj akademik Cvitković predstavlja spektar teorija koje obrađuju religijski fenomen. Slojevitu priču o religiji autor gradi na suptilnim interdisciplinarnim teorijskim i empirijskim saznanjima o religijskim sistemima.

Na samom početku autor navodi kako "za sociologa, religija nije ono što je zapisano u svetim spisima, ono što ljudi misle o Nadnaravnom i svetom, već ono što oni rade u ime tih svetih spisa, Nadnaravnog i svetog". Religija se posmatra kao društveni i grupni fenomen, a religijska zajednica kao institucionalizovana religija (Cvitković 2016: 12-13). Uloga teorije u sociologiji, kao i generalno u nauci, može biti vodilja empirijskog istraživanja ili njegov konačni rezultat (Bryman 2012). Prema tome, sociološke teorije o religiji su modeli kojima se pokušava objasniti njeno funkcionisanje u društvu (Cvitković 2016: 19). Podrobno ih analizirajući, Cvitković zaključuje kako se ni za jednu ne može kazati da je lažna, ali se zato za svaku može reći da je neopotpuna u pokušajima da objasni religiju (Cvitković 2016: 20-21).

Analiza započinje klasičnom funkcionalističkom i neofunkcionalističkom, odnosno marksističkom i neomarksističkom teorijom, zatim prelazi na teori- 
ju sukoba, postmodernističke, sekularizacijske, feminističke, globalizacijske, ekološke, fundamentalističke, teorije o humanizmu, teorije identiteta i pravne teorije i završava altruističkom, antropološkom, kreacionističkom, konstruktivističkom, teorijom racionalnog izbora i strukturalističkom teorijom, kao i poglavljima o međuodnosu tehnologije i religije i o verskoj zabrinutosti.

Funkcionalisti su bili preokupirani sadašnjošću i nastojali su da odgovore na pitanje kakva je aktuelna funkcija ili uloga religije u društvu. Utemeljivači funkcionalističke teorije su Ogist Kont, Herbert Spenser, Emil Dirkem, Bronislav Malinowski i Radcliffe-Brown. Kont je govorio o "religiji čovečanstva" i o ideji "jedinstva" koja povezuje sve aspekte ljudske prirode. Uloga religije je da uravnoteži i adaptira individualnu prirodu i poveže različite subjekte. Politički karakter takve religije sastoji se u usavršavanju čovečanstva na fizičkoj, intelektualnoj i moralnoj razini (Cipriani 2015). Dirkem naglašava sociološku dimenziju u proučavanju religije, čime ističe njenu kolektivnu, grupnu i institucionalnu ulogu. Svoje proučavanje zasnovao je na spoljašnjim, "vidljivim" dimenzijama religioznosti (Cvitković 2016: 44). Malinovski je govorio o mitološkoj osnovi magije. Svaki običaj, ideja i verovanje imaju svoju društvenu funkciju ili društveni zadatak (Taševa 1999). Radcliffe-Brown je primenjivao metod strukturalno-funkcionalne analize kako bi istraživao društvenu strukturu. Za demonstriranje čvrste veze između religije i društvene strukture koristio je bogat empirijski materijal iz Australije. Tvrdio je da verske prakse jačaju socijalne veze i socijalna pravila, kao i da neguju moral i zakone (Cipriani 2015: 59). Talcot Parsons je u svojim istraživanjima društvene funkcije religije naglašavao da se moraju uzeti u obzir različitosti i istorijske okolnosti razvoja svakog pojedinačnog društva. Religija, pored integrativne, može imati i dezintegrativnu funkciju. Kakva će ona biti zavisi i od društvenog okruženja, od dostignutog nivoa individualizacije, kao i toga da li je religija privatna ili javna, "vidljiva" ili "nevidljiva" itd. (Cvitković 2016: 52).

Veoma popularna i uticajna teorija u sociologiji religije je teorija o kompenzacijskoj ulozi religije Starka i Benbridža. Autori smatraju da je religija nastojanje da se zadovolje želje ili da se obezbede nagrade. Pod nagradama se podrazumeva sve što ljudska bića žele ili za čije su ostvarenje voljna da nešto ulože (Hamilton 2003: 353). Maks Weber u svom istraživanju upoređuje dve varijable sadržane u samom naslovu njegovog glasovitog dela Protestantska etika i duh kapitalizma i zaključuje da im je zajednički imenitelj ideja o pozivu. Naime, smatra da je i kod kapitalizma i kod protestantske etike rad uzdignut na nivo najsvetije čovekove dužnosti i da predstavlja najveći izraz čovekovog samopotvrđivanja (Taševa 1999; Cipriani 2015). Neofunkcionalisti 
govore o pluralizmu religija ukazujući na mirnu koegzistenciju različitih pogleda na svet. Pluralizacijom religija, sve se veća pažnja posvećuje fenomenu individualizacije religije. Na kraju poglavlja, nameće se zaključak kako su i funkcionalisti i neofunkcionalisti zanemarili ideološku funkciju religije. Detaljnom analizom funkcionalističke teorije religije, Cvitković postavlja temelj daljoj nadogradnji ili sastavljanju mozaika ostalih funkcija religije u društvu.

Karl Marx i Friedrich Engels osnivači su marksističke teorije i njihova dela se ubrajaju u klasične sociološke radove. Cvitković upozorava da se treba napraviti razlika između Marksovog učenja i marksizma. Marks jeste najpoznatiji po krilatici da je religija opijum naroda, izražavajući preko nje kritiku religije kao društvenog protesta. Sociološka dimenzija Marksove teorije religije ogleda se u tome što umesto kritike neba vrši kritiku zemlje, umesto kritike religije kritiku prava; rečju, kritiku teologije pretvara u kritiku politike (Cvitković 2016: 74-75). Sledi veoma kratak osvrt na kritičku teoriju Frankfurtske škole (Max Horkheimer, Teodor Adorno, Eric Fromm, Herbert Marcuse, Karl Korsch, Walter Benjamin, zatim Jürgen Habermas). Ovim se poglavljem Cvitković pokazao kao vrstan poznavalac marksističke i neomarksističke teorije o religiji.

Pobornici teorije sukoba analiziraju religiju prvenstveno kao mogući osnov ili izvor tenzija i konflikta u datom društvu. Istorijski narativ pruža bazu podataka o religijskim zajednicama uključenim u različite tipove konflikta i sukoba (hladni rat, raspad višenacionalnih država, etnički sukobi itd.). Cvitkovićevo mišljenje je da će nacionalni, religijski i kulturni identiteti određivati sukobe u 21. veku. Religije same po sebi nisu konfliktne, ali nam je istorija svedok toga da su doprinosile narastanju konflikata ili njihovom smirivanju. Povezanost religije i nasilja nije se manifestovala samo u prošlosti, ima je u velikoj meri i u sadašnjosti (Cvitković 2016: 89).

Današnja religijska mapa sveta ukazuje na postojanje mnoštva religija, a postmodernistička teorija insistira na tome da se sve one moraju priznavati i uvažavati.

Sekularizacijska teorija u sociologiji religije posmatra se kroz potiskivanje religije iz javnog prostora u privatnu sferu. U tom kontekstu, sekularizacija vodi rasterećenju religijskih institucija i otvara solidan prostor za bavljenje duhovnošću.

Feminističke teorije nisu anti-muške teorije, već su teorije koje zagovaraju interdisciplinarni pristup mestu i ulozi žene u društvu. Suštinski su usmerene protiv androcentrizma (koji svodi žene na potrošačice religijske kulture). Ovaj deo knjige pruža mnoštvo primera o tome kako se različite religije ophode prema ženi i koja su mainstream pitanja koja se u tom kontekstu postavljaju. 
U okviru globalizacijskih teorija autor postavlja pitanje do kakvih promena u ponašanjima dovodi globalizacija? Dve se izdvajaju: potenciranje dijaloga među religijama i uvažavanje slobode "drugoga” (Cvitković 2016: 229).

U suočavanju sa ekološkim problemima u novom milenijumu, religije i religijske zajednice trebaju iskazati mnogo veće interesovanje nego što su to činile do sada. Ekološki aktivizam verskih zajednica može doprineti daljem razvoju ekološke svesti i ispisati važne stranice u formulisanju jedne nove ekološke etike u svetskim razmerama.

U nastavku knjige profesor Cvitković elaborira i brojne druge teorije (fundamentalizam, humanizam, teorije identiteta, pravne teorije) zaokružujući na taj način možda i svoje najvažnije delo iz oblasti sociologije religije.

\section{Literatura}

Baloban, S. (2006), Socijalni nauk Crkve u Hrvatskoj. Katedra socijalnog nauka Crkve, Bogoslovska smotra, god. 76, br. 4, str. 1013-1027.

Bell, D. (1977), The Return of the Sacred? The Argument on the Future of Religion, British Journal of Sociology, Vol. 28, No. 4.

Bell, C. (2009), Ritual Theory, Ritual Practice, Oxford University Press, New York.

Бергер, П. Л. (2010), Православље и глобални плурализам, У: Д. Б. Ђорђевић - М. Јовановић (прир.) Могућности и домети социјалног учења православља и Православне цркве, Фонација Конрад Аденауер / ЈУНИР, Београд / Ниш, стр. 347358.

Биговић, Р. (ур.) (2011), Хришћанство и европске интеграције, Хришћански културни центар, Београд.

Blagojević, M. (2005), Religija i crkva u transformacijama društva, Institut za filozofiju i društvenu teoriju / I. P. "Filip Višnjić", Beograd.

Bosanac, M. - Mandić, O. - Petković, S. (1977), Rječnik sociologije i socijalne psihologije, Informator, Zagreb.

Cacanoska, R. (2011), Public Religion. U: Procedeing for profesor Vladimir Mitkov, Law University, UKIM, Skopje.

Cipriani, R. (2015), Sociology of Religion, Transaction Publishers, New Brunswich / London.

Cvitković, I. (2005), Religije suvremenoga svijeta, DES, Sarajevo.

Cvitković, I. (2007), Socijalna naučavanja u religijama, Nacionalna i univerzitetska biblioteka Bosne i Hercegovine, Sarajevo.

Cvitković, I. (2007b), Sociologija religije, DES, Sarajevo.

Cvitković, I. (2013), Encountering Others (Religious and Confessional Identities in Bosnia and Herzegovina), Yugoslav Society for the Scientific Study of Religion, Niš.

Cvitković, I. (2014), Sociologija obreda, Nacionalna i univerzitetska biblioteka Bosne i Hercegovine, Sarajevo.

Cvitković, I. (2016), Religija u zrcalu teorija, Centar za empirijska istraživanja religije, Sarajevo.

Davie, G. (2007), Sociology of Religion, Sage Publications, London.

Durkheim, E. (1982), Elementarni oblici religijskog života, Prosveta, Beograd. 
Doprinos akademika Ivana Cvitkovića razvoju sociologije religije (Povodom 75. godišnjice života)

Đorđević, D. B. - Todorović, D. (2001), Religijska većina o religijskoj manjini. U: Interreligijski dijalog kao vid pomirenja u Jugoistočnoj Evropi, BOŠ, Beograd.

Đurić Đorđević, M. (2010), Ritual smrti na fotografijama, Matica, br. 44, str. 167-174.

Ellison, C. G. - Sherkat, D. E. (1995), The Semi-involuntary Institution Revisited: Regional Variations in Church Participation among Black Americans, Soc. Forc., br. 73, str. 14151437.

Fox, J. (2018), An Introduction to the Religion and Politics, Routledge, London / New York.

Gerc, K. (1998), Tumačenje kultura, Čigoja štampa, Beograd.

Hamilton, M. (2003), Sociologija religije, Clio, Beograd.

Hamilton, M. (2007), The Sociology of Religion. U: Christopher Partridge (ur.) The New Lion Handbook: The World's Religions, 3rd ed. Lion Hudson Plc.

Cazeneuve, J. (1986), Sociologija obreda, Založba ŠKUC, Ljubljana.

Knoblauch, H. (2004), Sociologija religije, Demetra, Zagreb.

Kristić, A. (2018), Ekologija kao najveći religijski izazov u XXI veku, Znakovi vremena, br. 82, str. 153-176.

Lič, E. (1983), Kultura i komunikacija, Prosveta, Beograd.

Malinovski, B. (1971), Magija, nauka, religija, Prosveta, Beograd.

McGuire, M. (1992), Religion: The Social Context, Wadswort Inc.

Papsko veće za pravdu i mir (2006), Osnove socijalnog učenja Katoličke crkve, Fondacija Konrad Adenauer / Beogradska nadbiskupija, Beograd.

Pejić, S. (2017), Sociološka sinteza biopsihosocijalnih aspekata rituala: integrativni pristup, doktorska disertacija, Univerzitet u Novom Sadu - Filozofski fakultet, Odsek za sociologiju, Novi Sad.

Povrzanović, M. (1987), Pojmovi običaj, navika, obred/ritual, ceremonija, slavlje, svečanost i praznik u jugoslovenskim i inozemnim rječnicima enciklopedijama i leksikonima, Narodna umjetnost, br. 24, str. 39-81.

Radcliff-Brown, R. A. (1952), Structure and Function in Primitive Society, Cohen \& West Ltd., London.

Redklif-Brown, A. R. (1982), Struktura i funkcija u primitivnom društvu, Prosveta, Beograd. Руска православна црква (2007), Основи социјалне концепције Руске православне цркве, Беседа, Нови Сад.

Spickard, V. J. (2007), Micro Qualitative Approaches to the Sociology of Religion: Phenomenologies, Interviews, Narratives, and Ethnographies. U: A. J. Beckford - N. J. Demerath (ur.) The Sage Handbook of the Sociology of Religion, III. Sage Publications.

Šušnjić, G. (1998), Religija, I, Čigoja štampa, Beograd.

Taševa, M. (1999), Sociološki teoriji, UKIM, Skopje.

Тодоровић, Д. (2014), Српска православна црква на почетку трећег миленијума. У: Д. Б. Ђорђевић - П. Стајић - Д. Тодоровић (прир.) Хришћанство у 21. веку, Прометеј / Лесковачки културни центар / ЈУНИР, Нови Сад / Лесковац / Ниш, стр. 161-176.

Todorović, D. (2019), Tolerance, Multiculturalism and Interculturalism in the Balkans, Facta Universitatis: series Philosophy, Sociology, Psychology and History, Vol. 18, No. 1, str. 1-19.

Turner, W. V. (1977), The Ritual Process: Structure and Anti-Structure, Cornell Paperbacks, Cornell University Press, New York.

Van Genep, A. (2005), Obredi prelaza, SKZ, Beograd.

Vranješ, N. (2010), Izazovi socijalnog pastorala na području javnosti, Riječki teološki časopis, god. 18 , br. 2, str. 457-480.

Vrcan, S. (1986), Od krize religije k religiji krize, Školska knjiga, Zagreb. 